\title{
Mulheres com contratos de integração para a produção de dendê no Pará: redefinindo relações de gênero?
}

\author{
Integration Contracts for women in the production of palm oil in Pará: is it \\ redefining gender relations? \\ Dalva Maria da Mota $^{1}$ (D), Diocélia Antônia Soares do Nascimento² (D), Heribert Schmitz ${ }^{3}$ (D) \\ ${ }^{1}$ Embrapa Amazônia Oriental (Cpatu), Belém (PA). E-mail: dalva.mota@embrapa.br \\ ${ }^{2}$ Instituto Amazônico de Agriculturas Familiares (INEAF), Universidade Federal do Pará (UFPA), Belém (PA), Brasil. \\ E-mail: diocelianascimento@yahoo.com.br \\ ${ }^{3}$ Universidade Federal do Pará (UFPA), Belém (PA), Brasil. E-mail: heri@zedat.fu-berlin.de
}

\begin{abstract}
Como citar: Mota, D. M., Nascimento, D. A. S., \& Schmitz, H. (2020). Mulheres com contratos de integração para a produção de dendê no Pará: redefinindo relações de gênero? Revista de Economia e Sociologia Rural, 58(3), e192796. https://doi.org/10.1590/1806-9479.2020.192796
\end{abstract}

Resumo: Ser oficialmente responsável por um contrato com uma agroindústria para a produção de uma commodity é um fato recente para mulheres na Amazônia, apesar do seu protagonismo na reprodução social de numerosos grupos domésticos. Considerando a assimetria histórica da construção social entre trabalho de homens e trabalho de mulheres, o objetivo deste artigo é analisar se o contrato em nome de mulheres para a produção de dendê em estabelecimentos familiares influi em seu reposicionamento nas esferas doméstica e pública. No Pará, as mulheres são titulares de $20 \%$ dos contratos para a produção de dendê. A pesquisa foi realizada em São Domingos do Capim (PA) por meio de entrevistas semiestruturadas e abertas com todas as mulheres titulares de um contrato. Foram efetuadas observações nos seus lugares de residência (casa e estabelecimento) e de convívio social. As principais conclusões são: i) a titularidade do contrato e a gestão do cultivo do dendê no estabelecimento coincidem com $10 \%$ dos casos; ii) há reposicionamento das mulheres quando a assinatura do contrato está associada à titularidade da terra e a experiências associativas e econômicas; iii) todas as mulheres estão envolvidas em um processo de aprendizagem social, mas o reposicionamento ocorreu apenas com $10 \%$ delas.

Palavras-chave: dendeicultura, agricultoras, agricultura integrada, Amazônia.

\begin{abstract}
To be formally in charge of commodities production contracts in agribusiness is a recent phenomenon for women in the Amazon region, despite their important role in the social reproduction of many households. Given the socially constructed historic asymmetry between men and women, the aim of this paper is to analyze whether the women's name on palm oil contracts in family farms has an impact on their social repositioning within both the domestic and the public sphere. In Pará women hold $20 \%$ of palm oil production contracts. The research was carried out in São Domingos do Capim (Pará) and involved open and semi-structured interviews with all women holding a contract. Observations were carried out in their places of residence and with regard to their social life. The main conclusions were: i) Palm Oil production contract-holding and cultivation management coincide in $10 \%$ of cases; ii) women's social repositioning occurs when the signing of contracts is associated to land ownership and associative and economic experiences; and iii) all women are involved in a process of social learning. However, only $10 \%$ achieved a new position.
\end{abstract}

Keywords: Oil palm cultivation, women farmers, contract farming, Amazon region. 


\section{Introdução}

Nas duas últimas décadas, o dendê (Elaeis guineensis) tornou-se uma das culturas que mais rapidamente se expandiu no estado do Pará, na Amazônia Oriental, amparado em iniciativas de políticas públicas ${ }^{1}$ para a expansão de oleaginosas no Brasil.

Segundo estudo recente, 1.508 famílias e 181 produtores de médio porte estavam integrados à cadeia produtiva da oleaginosa em 2017, totalizando 20\% dos 207 mil hectares de dendê cultivados no Pará (Brandão et al., 2018). A iniciativa não é nova nem isolada, considerando que a demanda da indústria pelo óleo de dendê para o processamento de alimentos, cosméticos, produtos de limpeza e, mais recentemente, agrocombustíveis, sob argumentos ambientais, aqueceu os mercados e contou com o apoio do estado na Ásia, na África e na América Latina nas últimas décadas (Laschefski, 2010).

A recente expansão da dendeicultura na Amazônia Oriental provocou um acirrado debate, no qual argumentos econômicos, ambientais e sociais são confrontados, tomando experiências internacionais e locais como referências. As vantagens listadas destacam o preço do óleo de dendê em comparação com o de outros produtos (soja e linhaça, por exemplo) e a importância dos agrocombustíveis, que, por serem biodegradáveis e oriundos de fontes renováveis de biomassa, são vistos como "ecologicamente corretos", em contraste com os fósseis (Caseiro, 2011; Monteiro, 2013). Além disso, os cultivos ocupariam áreas consideradas degradadas, movimentariam a economia por meio da geração de empregos e renda e incentivariam a abertura de pequenos negócios no espaço rural (Alves, 2011; Becker, 2010; Homma \& Vieira, 2012). Vozes críticas, não obstante, contrapõem-se e apontam impactos ambientais decorrentes dos monocultivos (contaminação de águas e solos, desmatamento), desestruturação de modos de vida locais, concentração de terra, insegurança alimentar, perda de autonomia dos agricultores, pouca inserção das mulheres, aumento da violência, entre outras objeções (Backhouse, 2015; Brandão \& Schoneveld, 2015; Castro, 2012; Laschefski, 2010; Repórter Brasil, 2013; Vieira \& Magalhães, 2013).

Independentemente da posição dos analistas, do modelo de produção e das referências empíricas, as análises da participação de mulheres na produção de dendê não são frequentes nem animadoras. Li (2014), em estudo sobre a plantation na Indonésia, chamou a atenção para a desigualdade de gênero nas contratações de trabalhadores, com prioridade para os homens em empregos ocasionais. Outros autores têm mostrado que a produção de dendê tem provocado o fenômeno da "masculinização" da força de trabalho em decorrência do controle da terra, da facilidade de migração e da preferência por homens jovens no assalariamento em diferentes partes do mundo (Arndt et al., 2011; Li, 2014; Sampaio, 2014). Em consequência, constatou-se a "feminização" da agricultura de alimentos com uma maior carga de trabalho doméstico para as mulheres (Norwana et al., 2011; Ribeiro, 2016), o enfraquecimento dos meios de subsistência e também uma maior participação das mulheres nas discussões na comunidade e na negociação com as corporações (Julia \& White, 2012). Sob tais condições, as mulheres transitam entre produção e reprodução para garantir o aprovisionamento dos seus grupos domésticos, contrariando a visão que as associa, predominantemente, à reprodução (Reigada, 2014).

No Pará, a tendência é de "masculinização" da força de trabalho (Sampaio, 2014), quer seja no assalariamento nas empresas - as mulheres contam apenas com 13\% do total de contratação em 2013 (Costa, 2016) -, quer seja nos estabelecimentos familiares nos quais um dos membros tem contrato para a produção de dendê. Nestes últimos, sob o argumento de força física, o trabalho tem se concentrado nos homens, e apenas ocasionalmente as mulheres se dedicam ao dendê (Ribeiro, 2016; Silva, 2016; Vieira, 2015).

\footnotetext{
1 Um conjunto de iniciativas de políticas públicas foi posto em prática, como o Programa Nacional de Produção e Uso de Biodiesel (PNPB), lançado em 2004, e o Programa de Produção Sustentável de Óleo de Palma (PSOP), de 2010. O PNPB estabelece as condições para a participação da agricultura familiar, por meio do Selo Combustível Social (SCS), em uma perspectiva de inclusão social, determinando quanto da matéria-prima adquirida pelas agroindústrias para a produção de biodiesel deve vir da agricultura familiar, segundo cada região do país. O PSOP normatiza instrumentos como o crédito para agricultores familiares (Pronaf Eco Dendê) e incentiva agroindústrias a se estabelecerem no nordeste paraense.
} 
Apesar da eventualidade do trabalho das mulheres, elas são as titulares de $20 \%$ dos contratos para a produção de dendê no Pará. Quais são as razões pelas quais as mulheres assinaram um contrato de integração com as agroindústrias? A condição de titular influi no seu reposicionamento nas esferas doméstica e pública e, consequentemente, nas relações de gênero? Eis as perguntas a serem respondidas neste artigo.

\section{A pesquisa}

Considerando a assimetria histórica da construção social entre trabalho de homens e trabalho de mulheres, o objetivo deste artigo é analisar se o contrato em nome de mulheres para a produção de dendê em estabelecimentos familiares influi em seu reposicionamento nas esferas doméstica e pública. Por reposicionamento compreende-se a mudança vivenciada por mulheres rumo a uma situação de protagonismo nas ações realizadas nas esferas doméstica e pública relacionadas à dendeicultura.

A hipótese é que a assinatura do contrato influi no reposicionamento das mulheres i) quando está ligada com o título da terra, ii) quando a decisão de assinar o contrato é tomada por elas e iii) quando elas são casadas e têm filhos.

A pesquisa está situada no campo da sociologia rural e do trabalho. Adotou-se a orientação de Hirata \& Kergoat (2008, p. 266) quanto à existência de princípios na divisão sexual do trabalho, considerando que há separação (trabalhos de homens e trabalhos de mulheres) e princípio hierárquico (um trabalho de homem "vale" mais do que um trabalho de mulher). Os princípios expressam

[...] uma rígida separação entre a esfera da 'produção', associada exclusivamente à produção de mercadorias (valor de troca), e a esfera da 'reprodução' reduzida a tarefas historicamente atribuídas às mulheres no interior da casa (valor de uso) (Reigada, 2014, p. 24).

Concorda-se com Reigada (2014) quanto à crítica à rígida separação entre as noções de produção e de reprodução, separação que, por sua vez, sugere uma barreira forte e hierarquizada entre a esfera do mercado e a esfera doméstico-familiar, inexistente na prática pelas intersecções entre ambas.

Esta análise é parte de uma pesquisa maior realizada no âmbito do projeto AFInS e baseia-se em um estudo realizado em São Domingos do Capim, no nordeste paraense (NEP). Nesse município, 198 agricultores (89\%) e 30 agricultoras (11\%) têm contrato de integração em seus nomes para a produção de dendê com duas agroindústrias desde 2012 (Banco da Amazônia, 2015).

A pesquisa foi realizada por meio de entrevistas semiestruturadas e abertas com todas as mulheres ${ }^{2}$ titulares de um contrato no município. Para tanto, fez-se uma visita exploratória na qual, em conversas espontâneas com agricultores, técnicos e lideranças sindicais, identificaram-se mulheres que tinham contratos em seus nomes. A partir daí, todas elas foram visitadas e entrevistadas em suas residências. Nessas ocasiões, tanto se realizaram as entrevistas como as observações de suas atuações na casa, no estabelecimento e em outras esferas sociais (igreja, associações e sindicatos).

\section{Mulheres na dendeicultura: trabalho e contratos de integração}

Estudos sobre a participação de mulheres nas atividades correlatas à dendeicultura não são frequentes nem animadores. Quando disponíveis, tratam das consequências da produção de uma commodity nos modos de vida locais, na diferenciação social associado à etnicidade e ao gênero e no aumento do trabalho para as mulheres. Em geral, trata-se de estudos de caso na Indonésia e na Malásia, onde $85 \%$ da área cultivada de dendê é encontrada.

\footnotetext{
2 Identificadas por nomes de flores para garantir o anonimato.
} 


\subsection{Mais trabalho para as mulheres na dendeicultura?}

Em um estudo sobre monocultivos em um distrito da Indonésia, Li (2014) tratou da desigualdade de gênero vigente nas contratações com prioridade para homens em empregos ocasionais. A autora especificou dois períodos que demarcam as particularidades dos regimes de trabalho na dendeicultura: inicialmente, os membros do grupo doméstico são incorporados como assalariados ou agricultores no seu conjunto, com preocupações expressas quanto ao bem-estar do grupo; posteriormente, generalizam-se a casualização e a subcontratação, nas quais homens e mulheres, individualmente, competem por trabalho. No novo modelo, as famílias são relegadas à periferia do sistema, o que torna difícil manter os seus membros agrupados. Em consequência, acentua-se a dispersão espacial dos membros da família, com a tendência de trabalhos ocasionais para as mulheres (nos lugares em que vivem) e contratados para os homens (diferentes lugares) para maximizar os ganhos, sem garantia de que as fontes dispersas atenderão às necessidades da família.

No caso estudado por Li (2014), mulheres e homens locais são considerados menos apropriados para o trabalho por causa da pouca qualificação das primeiras e da falta de disposição e confiabilidade dos segundos. Migrantes são considerados como mais dependentes das empresas, mais facilmente disciplinados e sem alternativa para o trabalho, porque os estabelecimentos dos "camponeses" que pagam melhor estão distantes dos alojamentos. Assim, eles trabalham por um valor mais baixo, temem os riscos de prejuízo e os débitos pela viagem e têm consciência de que, não importa o quão duro trabalham, não acumularão, mas terão apenas o suficiente para sobreviver no dia a dia.

Ainda na Indonésia, Julia \& White (2012) analisaram uma experiência de perda do direito de mulheres à terra no processo de expansão da dendeicultura em uma comunidade na qual a plantação corporativa (plantation) e o sistema de agricultura por contrato minaram as suas posições. A passagem da posse da terra da comunidade para o Estado e a ação da burocracia em reconhecer o "chefe de família" por ocasião do registro da parcela corroeram o direito das mulheres àquele recurso.

Nesse processo de produção de commodity, as consequências mais visíveis têm sido uma nova divisão do trabalho, com a feminização do trabalho agrícola na parcela (para a comercialização e o consumo), a impossibilidade de acesso a outras fontes de renda e de alimento (produtos da floresta para consumo e artesanato) e o envolvimento na atividade ilegal de coleta de frutos caídos nos monocultivos. Não obstante a classificação, as mulheres têm papel central na reprodução social da família, estreitamente relacionado ao baixo nível de educação formal e ao direito de acesso à terra, além do trabalho no âmbito familiar e assalariado, conformando, inclusive, uma classe de trabalho (Julia \& White, 2012, p. 1005). Em contraste, a masculinização caracteriza-se pela posse legal da parcela em que são cultivadas as palmeiras, pela participação em organizações de produtores e pelo acesso a fontes de crédito, “[...] deteriorando a posição e os meios de subsistência das mulheres nesta sociedade já patriarcal" (Julia \& White, 2012, p. 1015).

Segundo Julia \& White (2012), as mulheres estavam ausentes em grande parte das discussões e negociações comunitárias sobre a distribuição da terra com as corporações que cultivam dendê e, mesmo assim, têm evidenciado a resistência como resposta.

De maneira similar a outros casos de "modernização" da agricultura, há um padrão familiar ambivalente, com tensão entre, por um lado, os atrativos do rendimento monetário regular e, por outro, a perda de posse de recursos e de autonomia, o que ajuda a explicar a experiência de coexistência, exploração, intimidação, consenso e resistência da comunidade (Julia \& White, 2012).

Norwana et al. (2011), em um estudo de caso na Malásia, constataram que a expansão do cultivo de dendê aumentou significativamente o volume de trabalho de quem permanecia em casa, principalmente as mulheres, que cozinham, limpam e cuidam das crianças e da gestão da família. Naquele contexto, notável fardo foi a coleta de água, porque o rio se tornou mais poluído, e suas águas, inadequadas para o consumo. Assim, as mulheres tinham de contar com a disponibilidade da água da chuva para executar tarefas domésticas. Ademais, os homens tinham menos tempo para ajudar em casa por causa do aumento da carga de trabalho. A menor disponibilidade de recursos naturais forçou também, em algumas famílias, 
as mulheres a sair para trabalhar, sendo, ainda assim, obrigadas a realizar a maioria das tarefas domésticas.

A partir de um enfoque mais geral, Arndt et al. (2011) afirmam que, em Moçambique, a expansão dos agrocombustíveis tem gerado crescimento bem como redução da pobreza, mas há restrições que limitam os benefícios advindos do aumento da participação das mulheres nos novos setores. Em esforço para examinar as implicações de gênero na expansão da produção em larga escala, os autores, amparados na literatura, reconhecem que as iniciativas relacionadas ao alto valor econômico são monopolizadas pelos homens, mas evidências indicam que, mediante as mesmas oportunidades, as mulheres podem ter o mesmo desempenho. Esses autores concluem que a expansão dos biocombustíveis terá implicações particulares para o bem-estar das mulheres, a partir da intensidade do envolvimento delas nas atividades agrícolas e não agrícolas.

Todos esses estudos têm em comum o detalhamento de processos vivenciados por homens e mulheres em diferentes partes do mundo para a produção de uma commodity destinada a mercados globais. Nos casos analisados, a intersecção entre os trabalhos considerados de homens e de mulheres opera segundo o princípio hierárquico de que aos homens competem maior flexibilidade (ir e vir) e ganhos regulares pelo assalariamento. A saída, entretanto, é possível, porque às mulheres é atribuída a responsabilidade pelo grupo doméstico. A tendência é haver expropriação e desagregação das famílias para garantir a subsistência.

Estudos exclusivos sobre relações de gênero ou mulheres na dendeicultura são raros. Uma precursora é Costa (2016), que analisou a atuação de lideranças femininas assalariadas na dendeicultura na diretoria de um sindicato de empregados rurais no Pará, Brasil. A autora ressalta como as diferentes experiências de homens e mulheres na vida pública influem em relações de poder hierarquizadas que colocam as mulheres em uma condição subalterna e de domínio masculino. Não obstante, iniciativas de resistência às adversidades, de enfrentamento familiar e de articulações externas começam a evidenciar-se, mas ainda sem romper estruturas de dominação que mantêm o sindicato como um espaço predominantemente masculino.

Em estudos em Tomé-Açu, no NEP, Sampaio (2014) e Ribeiro (2016) têm conclusões coincidentes ao afirmarem que, em $90 \%$ e $20 \%$ dos estabelecimentos, respectivamente, as mulheres adicionaram ao trabalho habitual as atividades da dendeicultura, especialmente a adubação. Os autores concordam que há desequilíbrios entre a disponibilidade de força de trabalho familiar e a demanda após o cultivo de dendê.

Vieira (2015) fez um estudo em uma das localidades precursoras da integração no município de Moju e constatou que o trabalho das mulheres foi intenso nos três primeiros anos no cultivo de dendê. Assim, todos os membros da família trabalharam na abertura da área, no plantio, na capina e no coroamento das mudas. Entretanto, com o início da produção e o recebimento dos recursos daí advindos, as mulheres foram substituídas por trabalhadores contratados. A partir desse momento, elas tinham trabalhado mais intensamente nas atividades do roçado ${ }^{3}$, o que configura uma divisão entre as culturas destinadas exclusivamente ao mercado e as destinadas predominantemente ao consumo, como também constatado na Malásia e na Indonésia (Julia \& White, 2012; Norwana et al., 2011).

Em São Domingos do Capim, no NEP, há divergências nos depoimentos sobre o trabalho de homens e mulheres na dendeicultura. "Dendê é muito pesado, mulher não aguenta não, é coisa de homem mesmo" (Lírio, 58 anos, agricultor, liderança). Diferentemente, uma entrevistada afirmou que realiza todas as atividades na dendeicultura (menos a aplicação de defensivos porque tem alergia) e aponta o seu companheiro como "ajudante":

\footnotetext{
3 “Na agricultura familiar da Amazônia prevalece o sistema tradicional da agricultura denominado agricultura itinerante, também chamado sistema de 'corte e queima' [...] caracterizado pelo uso de uma área de um a dois anos (roça) seguido por vários anos de pousio" (Schmitz, 2013, p. 347). Esse sistema refere-se apenas aos cultivos anuais, sendo o termo "roçado" utilizado, por isso, para todas as áreas com culturas anuais.
} 
Mas aí, eu continuei trabalhando, arranjando trabalhadores, pagando para fazer. E aí, estou tocando para frente e agora estou com esse companheiro que está me "ajudando", um cabra trabalhador também, do jeito que eu gosto, tudo eu que resolvo, aíi, graças a Deus, estou levando aí [...] Aí, os meninos [os técnicos da assistência técnica] riem de mim, porque eu digo assim, amanhã eu vou trabalhar, vou brocar, vou fazer o rodapé do dendê. O que tu pensas para fazer isso? Tu pensas que tu és homem? [o técnico falou] (Margarida, agricultora, 47 anos).

Mesmo que Margarida realize todas as atividades e a gestão do estabelecimento e afirme que o seu companheiro a "ajuda", em trechos da sua fala retoma o imaginário corrente, segundo o qual o trabalho "pesado" é coisa de homem, e o "leve", de mulher.

No mesmo município, uma técnica afirmou que "mulher trabalha arduamente ao lado do marido, trabalham tanto com o dendê quanto com a mandioca". A expressão "ao lado do marido" (e não "com o marido") denota uma maior valorização do trabalho do homem, mesmo que ela considere que as mulheres trabalham muito. Isso revela distinções percebidas por homens e mulheres quanto à diferença entre os sexos na realização do trabalho. Não obstante os raros indicativos de equidade no trabalho, as representações operam no sentido de atribuir maior poder aos homens.

Ao conjunto de atividades tradicionalmente realizadas, soma-se o dendê, com maior carga de trabalho para as mulheres, que persistem nas culturas alimentares, na criação de pequenos animais e como responsáveis pelas atividades domésticas. Persiste a tendência de concentração do trabalho das culturas comerciais nas mãos dos homens (pais e filhos mais velhos).

De maneira geral, as mulheres entrevistadas explicitam que "ajudam" os homens. Não obstante, exercem a "conciliação" entre o trabalho na casa e no estabelecimento e mantêm-se como responsáveis por transformar o produto oriundo do roçado em alimento para a família (Woortmann \& Woortmann, 2002).

\subsection{Mulheres com contratos de produção: um acontecimento mundial}

Estudo realizado por Raynolds (2002) sobre a produção sob contrato na República Dominicana apontou o crescimento do número de pequenos agricultores integrados a empresas do setor agroindustrial desde os anos 2000. Os contratos estão, predominantemente, assinados por homens, uma vez que são eles que detêm os direitos em quase todas as parcelas de terra resultantes da reforma agrária naquele país.

Segundo a autora, as especificidades dos contratos podem variar, mas todos têm como característica comum o comprometimento da terra da família, o trabalho e outros recursos para a produção da commodity controlada pela agroindústria (Raynolds, 2002, p. 783). Ademais, os contratos formais especificam os procedimentos de produção e de aquisição dos produtos como também os mecanismos de crédito e de estabelecimento de preços. No acordo, agricultores fornecem as terras e o trabalho, enquanto os compradores fornecem materiais, insumos químicos e/ou técnicas.

Para a autora, o termo "agricultura sob contrato" é tipicamente usado para descrever a produção de unidades familiares para empresas privadas, e o modelo prevalece graças à sua natureza econômica. Raynolds (2002) afirma que, na agricultura contratual, são mais frequentes produtos que usam mão de obra intensiva e nos quais tempo e qualidade são aspectos críticos, como as hortaliças. Por um lado, a produção sob contrato dá às agroindústrias um acesso sazonal a parcelas ecologicamente diversas e é mais comum quando terras de boa qualidade não estão disponíveis, são inacessíveis ou quando fazem parte de uma política de Estado para estabelecer uma iniciativa. Por outro lado, esse tipo de produção permite o acesso ao trabalho (flexível e dedicado) dos diferentes membros da família sem que seja necessário assumir questões trabalhistas: os produtores contratados são responsáveis por assegurar o desempenho adequado do trabalho manual e, como tal, orientam-se pelas relações de gênero, contando com as mulheres no planejamento do trabalho.

No Brasil, a agricultura por contrato com agricultores familiares data do começo do século XX. Adotada por volta de 1918 para a produção de fumo no Sul do Brasil, tornou-se 
uma prática comum na avicultura, na suinocultura e na produção de leite (Watanabe \& Zylbersztajn, 2014). Os autores reconhecem, porém, as particularidades do "agronegócio brasileiro" (Brazilian Agribusiness System - AGS) que:

Por um lado, o AGS brasileiro tem funcionado sem um quadro legal que especifique a agricultura contratual. Por outro lado, regras específicas para reger as relações do AGS brasileiro contribuiriam para a redução dos custos de transação, pois haveria maior transparência nas regras e, portanto, maior segurança para os agentes econômicos (Watanabe \& Zylbersztajn, 2014, p. 477).

Esse tema controverso foi objeto de análise no auge da modernização conservadora da agricultura (Anjos, 1995; Costa, 1993; Sorj, 1986). São emblemáticos os exemplos da criação de frangos e porcos e da produção de tomate, fumo e cana-de-açúcar desde os anos 1970. Nos anos 1990, o eucalipto e, mais recentemente, o dendê ganharam a cena. Nesse sistema, a agroindústria desincumbe-se da manutenção das estruturas de produção, mas "[...] mantém um monopólio de exploração e de controle sobre os trabalhadores familiares" (Nogueira \& Jesus, 2013, p. 127), inclusive quanto aos itinerários técnicos para a produção segundo padrões previamente estabelecidos e, normalmente, dependentes de crédito para serem postos em prática.

Na agricultura sob contrato, o descompasso entre o previsto e o realizado é objeto de conflito e até mesmo de ruptura do contrato. Sob diferentes olhares e experiências, estudiosos chamam a atenção para as assimetrias nas relações entre as partes contratuais no que concerne a informações. Os fornecedores (os agricultores integrados) são obrigados a aceitar as imposições das empresas, de modo que permanecem integrados a elas por falta de melhores alternativas de inserção econômica (Picanço Filho \& Marin, 2012). Os estudiosos destacam também os reflexos na organização da vida dos agricultores fornecedores de matéria-prima: diminuição da produção de alimentos e de frutíferas, redução do efetivo bovino, aumento do preço e escassez de mão de obra, masculinização da força de trabalho, entre outros reflexos (Aquino, 2013; Mota et al., 2015; Sampaio, 2014; Santos, 2015 ). A explicação para tais transformações é simultaneamente a redução das áreas destinadas às outras atividades, a concentração do trabalho na cultura sob contrato e a falta de incentivos para outras iniciativas (crédito, mercado e assistência técnica).

Há de se perguntar: por que, com tantas desvantagens, os agricultores aderem ao sistema de integração? A conclusão de Paulilo (1990), há mais de duas décadas, em contexto e em espaço diferentes, não obstante, ilumina a compreensão e indica que é a chance de ter uma cultura permanente com assistência técnica e participar do mercado. Estudo recente de Gaspari \& Khatounian (2016), em um assentamento de reforma agrária, mostra que os contratos de integração foram assinados sob o argumento da segurança de mercado. Entretanto, os autores afirmam:

O contrato é formalizado, mas isso não garante completamente o pagamento pela produção como efetivamente ocorreu na crise de capitais de 2008 , em que os estabelecimentos estudados integrados à agroindústria não receberam o pagamento da produção comercializada. Nesta via de venda, não há relação com os consumidores, e o prazo de recebimento é de 30, 60 e 90 dias (Gaspari \& Khatounian, 2016, p. 257).

Apesar de entendimentos divergentes, agricultores aderem aos contratos de integração porque têm esperança de um futuro diferente com crédito e assistência técnica. No caso do dendê no Pará, eles praticam uma agricultura com muitos problemas como a crise no sistema de "corte e queima", a podridão da mandioca, a falta de crédito, a ausência de assistência técnica e extensão rural e a falta de alternativas de trabalho para os mais jovens. Portanto, se, por um lado, a integração vai moldar a produção de dendê e de outras culturas, por outro facilitará o acesso a serviços e a garantia de mercado. Os argumentos elencados mostram um processo complexo no qual a autonomia no estabelecimento deve ser relativizada pelos ditames que o contrato impõe, mas aumentada pelas possibilidades de menor dependência dos mercados locais, incertos. 


\section{Dendeicultura em São Domingos do Capim: esperança e desconfianças}

O município de São Domingos do Capim tem uma área de 1.677 km², e seu Índice de Desenvolvimento Humano Municipal (IDHM) é de 0,532, correspondente à $118^{a}$ posição no conjunto dos 144 municípios do Pará. A população é de 29.846 habitantes, dos quais 22\% residiam na sede municipal, e 78\%, no campo (Instituto Brasileiro de Geografia e Estatística, 2015). As principais fontes de renda são a agricultura e o assalariamento. O município tem 2.628 estabelecimentos agrícolas, dos quais 113 são patronais, e 2.515, familiares, ocupando $37 \%$ e $63 \%$ da superfície agrícola, respectivamente (Instituto Brasileiro de Geografia e Estatística, 2017). Sete assentamentos de reforma agrária foram demarcados com 976 famílias assentadas nos anos 2000 (Instituto Nacional de Colonização e Reforma Agrária, 2015).

A economia de São Domingos do Capim depende da agricultura itinerante para o cultivo de mandioca, que é transformada em farinha, item essencial da alimentação e comercialização. Pimenta-do-reino, milho, cacau, feijão e dendê também são cultivados. Destaca-se ainda o extrativismo do açaí, da castanha-do-pará e da madeira (Instituto Brasileiro de Geografia e Estatística, 2015). Apesar da diversidade, os limitados incentivos financeiros e a carência de assistência técnica marcam as dificuldades, com exceção da dendeicultura. Esse fato é confirmado pela distribuição dos recursos oriundos do Programa Nacional de Fortalecimento da Agricultura Familiar (Pronaf) para cultivos permanentes entre janeiro de 2013 e junho de 2015: 50\% dos recursos foram para o dendê (R\$7.018.582,59), 35\%, para o açaí $(R \$ 4.875 .209,35), 8 \%$, para o cacau $(R \$ 1.093 .490,87)$, e $7 \%$, para a pimenta-do-reino (R\$ 1.076.604,46).

Como em outros municípios paraenses, o marco histórico para o incentivo à adesão à dendeicultura em São Domingos do Capim foi o lançamento do PSOP pelo então presidente Luiz Inácio Lula da Silva, em Tomé-Açu, em 2010, com a presença de representantes de organizações sociais, poder público, banco e empresas dendeicultoras ${ }^{4}$. Naquele momento, a popularidade do governo federal reforçou a esperança de produção de uma cultura permanente com assistência técnica, crédito e mercado a partir do modelo de agricultura com integração. Como afirmou uma agricultora, "Lula dizendo, por que eu não ia acreditar? Ele só trazia coisa boa pra nós, estava tudo ali" (Verônica, agricultora, 49 anos). Reforçava o otimismo e a estratégia de convencimento posta em prática pelas empresas interessadas no cultivo de dendê naquele município por meio da ação de técnicos e lideranças sindicais ${ }^{5}$.

Naquelas circunstâncias, a empresa Archer Daniels Midland (ADM) objetivava construir uma usina de processamento de dendê no município de São Domingos. A promessa declarada pela ADM contava com a integração de 600 famílias (até 10 ha), respondendo por $50 \%$ da produção a ser processada, enquanto a outra metade seria produzida no sistema de plantation da própria empresa, totalizando 12.000 ha de plantio na região (Nahum \& Murray, 2014; Nahum \& Santos, 2014).

Paralelamente, a prefeitura de São Domingos do Capim assinou um acordo de cooperação com a Empresa de Assistência Técnica e Extensão Rural (Emater) para estimular a efetivação dos procedimentos necessários à execução de assistência técnica aos agricultores familiares interessados na integração com as agroindústrias (Gomes \& Magalhães, 2016). O cultivo de dendê no município iniciou sob a ação de duas empresas, em 2010.

A esperança de ter serviços básicos e mercado fundamentou a decisão de muitos dos que aderiram ao contrato. Ademais, o cultivo de uma cultura perene associado à ideia de reflorestamento também funcionou no convencimento, bem como no acesso a serviços de assistência técnica.

Ainda assim, existem divergências, e agricultores que não aderiram ao contrato contra-argumentam com o medo de perder o acesso aos recursos e sua autonomia.

\footnotetext{
4 Federação dos Trabalhadores na Agricultura do Estado do Pará (FETAGRI), Sindicatos dos Trabalhadores e Trabalhadoras Rurais (STTR) da região, prefeituras municipais, Instituto Nacional de Colonização e Reforma Agrária (INCRA), Banco da Amazônia S.A. (BASA), empresários de agroindústrias de dendê, políticos nacionais, entre outros. ${ }^{5}$ Iniciativas dessa natureza também foram observadas na Indonésia, inclusive com ganhos financeiros para as lideranças políticas, religiosas e professores (Julia \& White, 2012).
} 
As divergências apontam também as consequências ambientais, e o modelo é questionado por agricultores e representantes dos movimentos sociais e da academia.

Mesmo com a polêmica, o dendê é cultivado em 226 estabelecimentos familiares em São Domingos do Capim (10\% do total) por meio de um contrato de integração em áreas que variam de 3 a 30 ha. A cultura foi financiada por crédito do Pronaf. Os contratos têm diferentes membros da família como titulares, havendo inclusive mais de um projeto de financiamento por estabelecimento em $12 \%$ dos casos. Do total dos contratos, $87 \%$ foram assinados por homens, e 13\%, por mulheres até o ano de 2015 (Banco da Amazônia, 2015).

No conjunto dos projetos financiados para a produção de dendê em estabelecimentos familiares no Pará, os homens (pais e filhos) são titulares em $80 \%$ dos contratos, e as mulheres (mães e filhas), em 20\% (Banco da Amazônia, 2015). A diferença explícita dos números reforça a compreensão dos princípios fundantes da divisão do trabalho quanto à existência de trabalho de homem e trabalho de mulher e à hierarquia posta em prática, com os homens predominando nas atividades públicas.

\section{Mulheres titulares de contrato em São Domingos do Capim: vontades e indiferenças}

As mulheres que têm contratos de integração em seus nomes para a produção de dendê se autodesignam simultaneamente como agricultoras, lavradoras e donas de casa e residem em 17 diferentes localidades do município (Figura 1). Para 70\%, o acesso à terra deu-se por via de regularização fundiária no formato assentamento da reforma agrária com as particularidades que a Amazônia revela, por tratar-se de uma "reforma agrária às avessas" (Magalhães, 2003) ${ }^{6}$, na qual o Estado atuou para regularizar terras já ocupadas por grupos de camponeses há décadas. As demais mulheres dispõem de terras compradas e herdadas.

Os seus contratos são celebrados com as empresas ADM e Biopalma da Amazônia S.A. e estão em vigência desde 2010. Entre os compromissos contratuais, as mulheres são responsáveis pela gestão do cultivo de dendê (itinerário técnico), pela comercialização com a empresa e pelo financiamento com o banco.

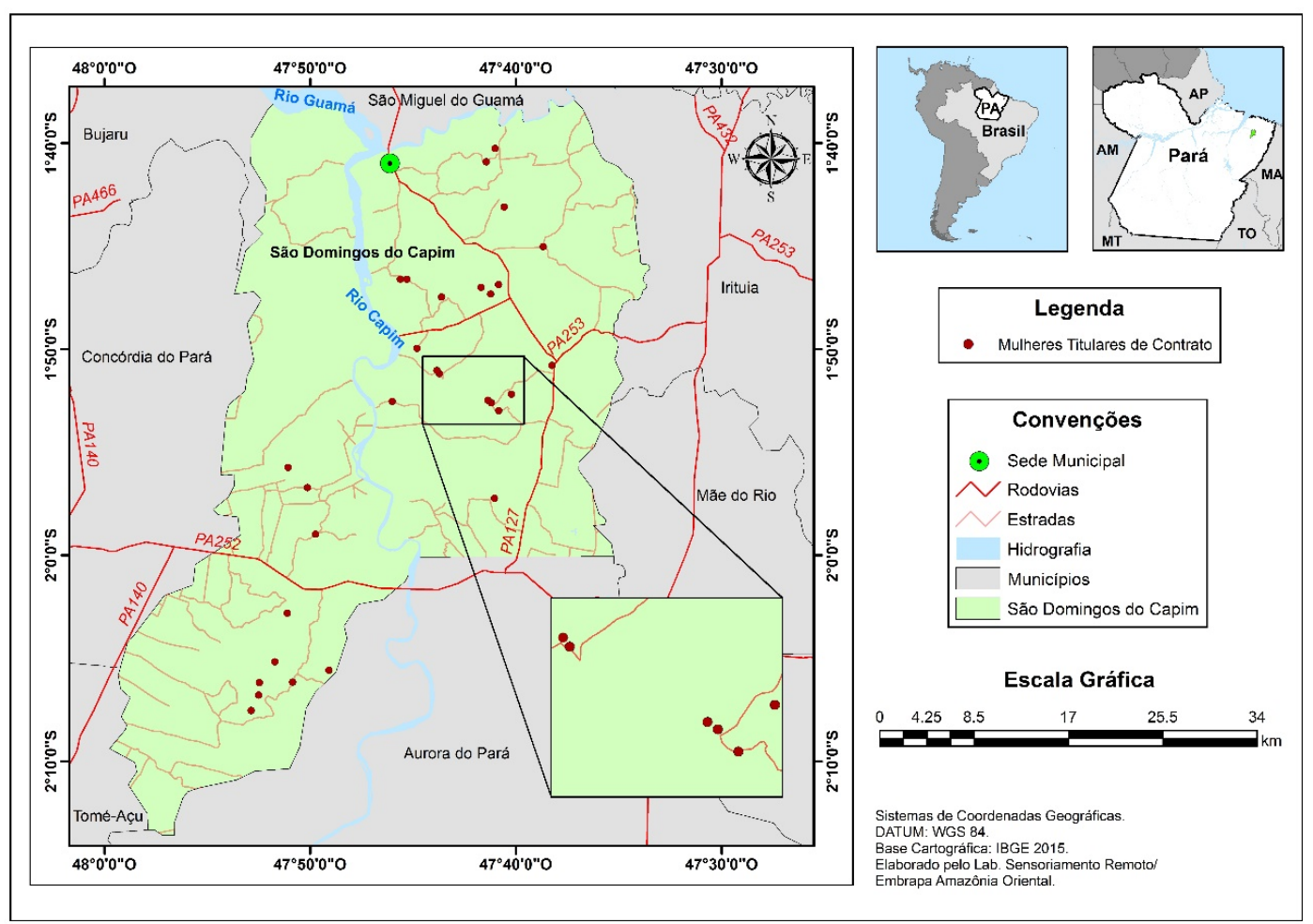

Figura 1 - Lugares de residência das mulheres com contrato entrevistadas em São Domingos do Capim (PA).

${ }^{6} \mathrm{~A}$ autora analisa que "a implantação dos assentamentos é, de fato, uma ação tardia do Estado de reconhecimento de uma situação de reforma agrária promovida pelos camponeses há quase duas décadas" (Magalhães, 2003, p. 248-249). 
Fonte: pesquisa de campo.

\subsection{Por que as mulheres assinaram contratos em seus nomes?}

Parte-se do pressuposto de que as mulheres têm razões, para além de motivações econômicas, que fundamentam a sua decisão de assinar contratos de integração em seus nomes com as agroindústrias do dendê no NEP. Tendo em conta a similitude da iniciativa, embora com grupos e em décadas diferentes, orientou-se a partir do estudo de Paulilo (1990) sobre a agricultura familiar integrada em Santa Catarina para compreender essas razões. Uma das conclusões da autora é: entre os contratantes, estabelece-se uma relação assimétrica em que uma das partes (o agricultor) tem, simultaneamente, consciência crítica e aceitação sem, entretanto, ver outra alternativa. Ademais, como afirmou uma agricultora no Pará (Aurora, 50 anos): "assisti na televisão que o presidente Lula ia implantar dendê na região de Tomé-Açu e que, se viesse pra São Domingos do Capim, eu ia pegar". A expectativa da implementação de uma política pública associou-se à confiança em uma liderança carismática em uma conjuntura em que as vantagens econômicas da dendeicultura e de infraestruturas para as localidades foram bastante divulgadas no processo de seleção para integrados.

Entre as atividades realizadas pelas mulheres entrevistadas que assinaram o contrato predominava o cultivo da mandioca, mas com muitos problemas: "[...] a roça morria muito" (Jasmin, 40 anos, agricultora); "[...] a roça não dava mais, estava morrendo tudo e a gente precisava plantar outras coisas" (Margarida, 47 anos, agricultora). A desesperança quanto ao cultivo da mandioca está relacionada ao problema da podridão radicular da planta, à flutuação dos preços, à concorrência com os produtos provenientes do Paraná e ao número de pessoas necessárias para o processamento em um contexto em que o trabalho de jovens e crianças está sob questionamento legal.

Outra razão frequentemente apontada é o desejo de que o futuro dos filhos seja diferente daquele dos seus pais:

Saber que tem um futuro, né? Empregar meus filhos, né? Eu penso isso. Por exemplo, quando meus meninos crescerem, é ter condição, não quero ver meus filhos trabalhando com a diária que eu dou, ganhar uma diária e uma diária você sabe como é né? Só dá mesmo para se manter (Sempre-Viva, 31 anos, agricultora).

As razões de duas mulheres chamaram atenção na pesquisa. Hortência (agricultora, 54 anos) e Bromélia (agricultora, 46 anos) aderiram à dendeicultura à revelia dos maridos, que temiam o insucesso, mas elas tinham claro que a família precisava de novas alternativas, e pesou na decisão a segurança do mercado. Do mesmo modo, Gérbera (aposentada, 81 anos) afirmou que "o contrato foi feito em meu nome para meus filhos trabalharem". Papoula (agricultora, 29 anos) explicitou que "o contrato é algo novo, diferente, e eu que sou responsável por ele, faço de tudo pra ele dar certo e melhorar a vida da família". Sempre-Viva (agricultora, 31 anos) afirmou que "Eu tenho fé em Deus que um dia eu vou fazer minha casa com o dinheiro do dendê né? Vou pagar a faculdade dela [a filha]".

Pelas narrativas, as decisões assemelham-se aos argumentos citados por Neves (2014, p. 33) sobre o engajamento econômico das mulheres na região de Santarém (PA):

[...] o objetivo fundamental das mulheres é se constituir como sujeito de ações para colaboração na melhoria das condições habitacionais e do grau de ensino para os filhos, especialmente se, acumulativos, eles puderem redundar em profissionalizações reconhecidas.

Como analisa a autora, trata-se de oferecer aos filhos e filhas melhores condições para que conquistem maior bem-estar. Isso não significa que temores estejam distantes das suas decisões, como explicado por Angélica (agricultura, 33 anos) neste estudo: "não queria o projeto com medo de ficar em dívida com o banco", mas foi convencida mediante o argumento da segurança de mercado que a dendeicultura traria.

Os relatos anteriores referem-se a 10 mulheres que optaram pela assinatura do contrato em um universo de 30 mulheres. Para além das razões econômicas e de segurança de 
mercado para a família, havia o entendimento de que a dendeicultura estaria associada à melhoria de infraestruturas como estrada, saúde e educação, pela via da parceria entre iniciativa pública e privada.

No outro grupo (um total de 20), as mulheres assinaram o contrato em atendimento à solicitação de um dos membros da família (pai, irmão ou marido) ou atenderam a uma decisão da família. Flor de Lis (agricultora, 45 anos) afirmou: "O projeto está no meu nome, porque meu marido quis". Segundo Orquídea (agricultora, 25 anos): "Meu pai já tinha um projeto no nome dele, e, como eu sou a mais velha e tenho documentos, aí ele resolveu". Os depoimentos são claros quanto a uma decisão externa à sua própria vontade sobre o modo de lidar com a cultura do dendê. Ademais, Mimosa (aposentada, 59 anos) e Nigela (aposentada, 66 anos) já não trabalham na agricultura, e Tulipa (agricultora, 48 anos) dedica-se exclusivamente a um pequeno comércio em sua residência, mas as três apresentavam as condições legais, e a família decidiu que o contrato seria assinado no nome delas para terem uma nova opção econômica e acesso a serviços.

Naquele momento, em 2010, o dendê era uma novidade e, como tal, um risco que poderia ocasionar sucesso ou fracasso do ponto de vista das estratégias de reprodução da família. O fato de o contrato estar no nome da mulher pode livrar os homens de terem seus nomes associados formalmente ao fracasso.

Houve, por parte dos que aderiram ao contrato, "uma aceitação racional da empresa que, embora não mude o caráter assimétrico da relação, justifica-a por motivos outros que não a coerção pura e simples ou a passividade" (Paulilo, 1990, p. 35).

As explicações são diversas para justificar por que as mulheres participaram de uma decisão da família segundo uma combinação que leva em consideração a disponibilidade de documentos, a avaliação da situação bancária de cada membro (livre de empréstimos, sem pendências financeiras), o projeto da família para as atividades produtivas e a necessidade de ocupação de algum dos seus membros.

Comparando-se as razões das mulheres para assumirem a titularidade do contrato, independentemente do tipo de decisão, constata-se que elas têm em comum o desejo de melhoria de vida da família que, naquele contexto, está associada à diminuição da dependência do cultivo da mandioca e à segurança de mercado pela participação em uma cadeia produtiva com forte suporte do estado. A integração possibilita o acesso a insumos e a colocação do produto no mercado (Paulilo, 1990).

A centralidade das relações de parentesco no grupo doméstico nuclear, a priori, fundamentou a decisão de ser titular do contrato. Por um lado, o enquadramento anteriormente conquistado pela política pública de reforma agrária, a partir de $2003^{7}$ - que possibilitou às mulheres serem consideradas como chefes de família e, assim, permitiu-lhes ter a terra em seus nomes -, funciona como um diferencial. Por outro, para a integração, as empresas privilegiam grupos familiares constituídos, considerando a demanda de mão de obra e a estabilidade.

\subsection{Reposicionamento na gestão e no trabalho para o estabelecimento familiar?}

No Pará, as atividades realizadas pelas mulheres na agricultura familiar geralmente são associadas ao domicílio, consideradas como trabalho doméstico, muito embora as mulheres desempenhem um papel crucial para os seus grupos domésticos na coleta de produtos da biodiversidade (Lima \& Mota, 2016), no trabalho no roçado (Motta-Maués, 1993), na pesca (Vieira et al., 2014) e no processamento de produtos (Ribeiro, 2016). Entre as suas atribuições também está a socialização das crianças para o trabalho, padrão também observado em localidades do Rio Grande do Sul (Wedig \& Menasche, 2013), onde a socialização dos filhos reproduz os mesmos modelos de socialização masculino e feminino, além de atividades na cidade como fazer compras, resolver assuntos escolares dos filhos ou documentos familiares e receber o Bolsa Família.

\footnotetext{
7 De acordo com a Instrução Normativa n 38/2007 (Brasil, 2020), o INCRA tornou obrigatória a inclusão de mulheres como beneficiárias da reforma agrária. Além disso, a Portaria n 981/2003 (Instituto Nacional de Colonização e Reforma Agrária, 2020), também do INCRA, definiu que, em casos de separação dos cônjuges, o lote, se ainda estiver em fase de regularização fundiária, deverá ficar sob a posse da mulher, desde que ela seja a responsável pela guarda dos filhos.
} 
Constatou-se nesta pesquisa que 24 mulheres (80\%) são responsáveis pelo trabalho doméstico. As atividades realizadas pelas mulheres no âmbito doméstico são fundamentais para a reprodução do grupo doméstico (Garcia Júnior, 1983), mas não são consideradas trabalho quando comparadas àquelas realizadas na produção. Apesar de muitas mulheres reconhecerem o caráter laboral das atividades domésticas, foi comum ouvir das próprias entrevistadas que elas "ajudam" nas atividades agrícolas.

Para Hirata \& Kergoat (2007), as razões para tal compreensão apoiam-se na divisão sexual do trabalho, alicerçada nos princípios de separação e hierarquia. Portanto, na agricultura familiar, convencionou-se afirmar que o roçado é o local de domínio do homem, e a casa, de domínio da mulher. Essa diferenciação atribui, por um lado, ao sexo masculino a esfera produtiva e, por outro lado, ao sexo feminino, a esfera da reprodução e, consequentemente, a aceitação das atividades feitas por homens como portadores de maior valor social (político, religioso, militar etc.).

Neste estudo, constatou-se que 23 mulheres (77\% do total) trabalham na agricultura (roçado). Todas se dedicam a atividades de plantio e processamento da mandioca e de outras culturas alimentares (feijão e milho) e comerciais (pimenta-do-reino e açaí). As 7 (23\%) que não trabalhavam no roçado são idosas e aposentadas. Naquele contexto, o roçado é concebido como espaço de homens e mulheres, mas publicamente é atribuído a estas últimas pelas razões explicitadas anteriormente. Diferentes arranjos são postos em prática para conciliar trabalhos dentro e fora da casa, segundo o tamanho do grupo doméstico e a disponibilidade de recursos, entre outros aspectos. Mesmo assim, a falta de reconhecimento do trabalho doméstico pontua os discursos das mulheres e marca as suas existências, como revela Sempre-Viva (31 anos, agricultora):

[...] quando eu não trabalhava na roça, que eu criava só os meninos, né? Então, eu cuidava só dos meninos, aí até meu marido mesmo falou - que até hoje eu não esqueço -, a gente é muito baixa, né? Aí, ele disse assim: “Rapaz, tu não faz nada, tu não presta, nem pra criar uma galinha?!", desse jeito!!! Ele falou isso aí e eu nunca esqueço [...].

No caso, a "ofensa" sofrida ao ser considerada sem capacidade para o trabalho impulsionou a mulher a contestar a hierarquia e a buscar um reposicionamento.

\subsection{Trabalho de mulheres na dendeicultura}

Das 30 mulheres que assinaram o contrato em São Domingos, 14 (59\%) simultaneamente executam as atividades domésticas, trabalham na roça e desenvolvem alguma atividade no dendê. Elas reconhecem que a quantidade de trabalho aumentou muito com o advento da dendeicultura. Interpreta-se nessa assertiva tanto o trabalho quanto as responsabilidades que implicam uma relação contratual. O acúmulo, entretanto, demanda rearranjos, com maior jornada de trabalho ou mudança de rotina, como explica uma entrevistada:

[...] porque eu deixo tudo que tenho que fazer e tenho que ir [realizar trabalho no dendê]. Aí eu faço quando eu chego [em casa], principalmente agora que a menina saiu, né? Aí, eu não ligo pra muita coisa não, quando chegar eu faço, aí as vezes eu só vou de manhã e de tarde eu faço e é assim (Sempre-Viva, 31 anos, agricultora).

Ainda em se tratando da quantidade do trabalho, o acúmulo tem influído também na organização das atividades agrícolas:

[...] porque, às vezes, tem que ter muito tempo para fazer as coisas, né? Por exemplo, a gente quer botar o açaizal. Oh, agora é o tempo de brocar a roça, né? Para preparar pra plantar. Aí, também nós temos que está cortando a palha, aí, na semana tem que cortar o dendê, às vezes, a gente não consegue nem, tem que deixar alguma coisa pra trás. E é porque nós não fazemos farinha, a gente já vende já a mandioca. E a nossa família é pequena, né? (Sempre-Viva, 31 anos, agricultora). 
O depoimento explicita que há superposição de atividades e priorização da dendeicultura considerando a força de trabalho disponível. A agricultura por contrato implica o cumprimento de um protocolo técnico, e, como tal, as demais culturas ficam no segundo plano, com consequências nas atividades tradicionalmente realizadas como a produção de farinha.

No geral, as entrevistadas classificam o trabalho na dendeicultura em oito atividades: plantio, roçagem, adubação, aplicação de agrotóxico, poda, coroamento, rebaixo e colheita.

O envolvimento das mulheres nas atividades de produção de dendê é bastante diferenciado. Das 10 mulheres que assinaram o contrato por decisão própria, duas não realizam atividades diretamente na dendeicultura, porque uma apenas administra o cultivo por meio do trabalho contratado e a outra repassou a atividade para os filhos. As oito envolvidas na dendeicultura realizam entre uma e oito atividades, inclusive aquelas consideradas mais pesadas como plantio, roçagem, colheita e aplicação de agrotóxicos, com tipicamente três atividades por mulher.

Das 16 mulheres que atenderam a apelos de familiares, nove não realizam nenhuma atividade relacionada ao dendê, porque não trabalham mais com a agricultura por serem idosas ou porque se concentram no roçado, ou ainda porque os homens a quem elas atenderam dedicam-se às atividades da dendeicultura. As sete mulheres que trabalham no dendê realizam entre uma e oito atividades, mas trabalham mais na adubação e no plantio, atividades consideradas mais leves naquele contexto.

As demais quatro mulheres não sabem explicar porque assinaram o contrato.

Como visto, há uma diversidade de arranjos para levar adiante o trabalho no dendê. Um dos homens entrevistados (Lírio, 58 anos, agricultor, liderança), quando questionado sobre o trabalho das mulheres, afirmou:

Até agora aqui não fazem nada. Aí vai chegar uma hora em que elas vão fazer o leve. No caso da dona Verônica [viúva], quando começar o corte, ela vai juntar muita fruta do dendê que, quando a gente corta, ele debulha um pouco [...] Aí, tem mulher também que ela trabalha no dendê direto. Ela faz poda, coroa no veneno.

Sobre uma vizinha, ele afirmou:

No caso da dona Rosa, eu acho que ela não trabalha, porque ela tem uma idade meio avançada. Muitos filhos, uma frota de filhos para fazer por ela. Jamais ela vai sair da casa dela. Ela coitada, mal dá conta da casa, que só é ela para tomar conta, ela lava roupa, apronta comida.

Inicialmente ele reluta em reconhecer que as mulheres trabalham e começa admitindo que fazem apenas trabalho "leve". Entretanto, ao dar exemplos, ele enumera casos e tipos de arranjos, segundo o tamanho da família, idade e estado civil e reconhece que elas realizam, inclusive, trabalhos por ele considerados "pesados".

Mesmo que a classificação do trabalho como leve e pesado seja associada naquele contexto a mulheres e homens, porque "[...] qualifica-se o trabalho em função de quem o realiza: são leves as atividades que se prestam à execução por mão de obra feminina e infantil" (Paulilo, 1987), as evidências empíricas mostram contrastes, conforme o depoimento a seguir:

Tem pessoas que dizem assim, égua, como é que tu consegue trabalhar, eu vou de bota, vou de chapéu, vou de blusa mangas compridas, às vezes, os meninos do dendê chegam até a me confundir e dizer: Ei, senhor! Quando eu viro, pedem desculpa. Desse jeito, chegam a me confundir. Quando é à noite, eu sei o que eu vou fazer pela manhã, eu digo assim: "amanhã, eu vou amanhecer com uma força de macho, mas uma força mesmo de um macho mesmo". Se eu não falar isso, talvez eu não dê conta, se eu falar, eu dou. Eles começam a rir de mim. Assim que eu venço (Margarida, agricultora, 47 anos).

Margarida é uma das quatro mulheres que realizam todas as atividades na dendeicultura. Segundo ela, a sua trajetória de mãe solteira, de socialização precoce para o 
trabalho e de "ter coragem" conforma-a como destemida e capaz de realizar qualquer atividade. Mas o peso do trabalho, nesse novo contexto, é também relativizado, porque há a compreensão de que o treino e a responsabilidade as capacitarão para tal:

Olha, quase tudo [é pesado], né? Porque para tirar a palha, eu fui tirar e só consegui tirar três, três árvores, mas dava para tirar mais, só que aconteceu logo [atingida por um espinho] isso que foi a primeira vez que fui tirar palha, né, aí aconteceu isso [...], tudo tem que ter um jeito, se a gente não tiver o jeito, aí tudo é difícil (Sempre-Viva, 31 anos, agricultora).

Como o depoimento mostra, há uma relativização do trabalho pesado por meio da expressão "ter um jeito", que é interpretada como a qualificação requerida para determinada prática. Os dois depoimentos mobilizam argumentos diferentes e são de mulheres que fazem a gestão do cultivo e têm autonomia para tomar decisões em relação ao itinerário técnico, cabendo a elas, inclusive, transmiti-lo a outros membros da família. O depoimento mostra também que Sempre-Viva assumiu a posição de gestora do cultivo e, mediante a assistência técnica, partilha-a com o marido, orientando-o. Aliás, o tema da gestão quase não pontua as suas falas, porque parece natural que seja uma atribuição dos homens.

As semelhanças entre essas mulheres quanto à titularidade da terra, à decisão própria de assinar o contrato e ao fato de serem casadas e com filhos (quatro filhos em média) permitem a confirmação da hipótese para um grupo minoritário. Outro aspecto em comum é a experiência com outros projetos de financiamento e também em movimentos sociais. Aurora (agricultora, 50 anos) afirmou ter participado de clube de mães e atualmente faz parte do grupo de mulheres da igreja.

Ao ser questionada sobre a participação em mobilizações, Margarida (agricultora, 47 anos) afirmou:

Em Belém tem o Grito da Terra, a Marcha das Margaridas, tem reunião, eu sempre vou quando o presidente da associação não pode ir, eu vou representar. Às vezes, eu vou representar minha igreja nas associações. Nesses lugares, eu sempre vou. Em Belém, quando tem essas coisas, eu gosto de participar.

As seis mulheres que atenderam ao apelo de familiares (pai, irmão ou marido), em meio a discórdias e convencimentos, informaram que ficou acertado que os homens seriam os responsáveis por todas as ações do projeto. Mesmo assim, elas trabalham em algumas das atividades. Elas têm idades entre 25 e 60 anos, duas são casadas, cinco têm sete filhos em média e somente três têm a titularidade da terra. As razões para a assinatura do contrato e a titularidade da terra diferenciam-nas sobremaneira do primeiro grupo, como também as experiências anteriores com financiamentos que nunca obtiveram. Não se constatou, portanto, nesse grupo um reposicionamento nas ações realizadas nos domicílios, tampouco nas atividades relacionadas à dendeicultura, muito embora tenham ampliado sua participação em outros espaços, como será analisado no próximo item.

\subsection{Reposicionamento na esfera pública?}

O reposicionamento na esfera pública está diretamente relacionado à intensidade do envolvimento das mulheres na dendeicultura, quer seja no espaço privado, quer seja no público. Para efeito deste artigo, examinou-se esse reposicionamento com base em três tipos de relação: intrafamiliares, intracomunitárias e institucionais.

Para as mulheres que fazem a gestão do cultivo, há uma ampliação de suas atribuições nas localidades em que vivem, porque partilham de uma condição comum com alguns vizinhos, o que implica uma nova experiência. O diálogo sobre as práticas e as dificuldades enfrentadas é frequente, segundo informam:

Por exemplo, os vizinhos, né, que eles têm a mesma cultura, a gente conversa, a mesma cultura é bom que um diz: 'Ah, eu já fiz isso'. E aí os teus quilos deu mais do que o meu, é assim [...] (Sempre-Viva, 31 anos, agricultora). 
Essas relações extrapolam o diálogo sobre aspectos técnicos e incidem também nas novas responsabilidades das mulheres. Daí frases com conteúdo de gozação, como "ela agora é a patroa" ou "ah, ela que é a chefe aí, ela que resolve". A elas também competem o contato com os técnicos da assistência técnica e o repasse das orientações aos demais membros da família. Nas palavras de uma delas, "é bom, dar minha opinião... é bom porque a gente se sente que tem valor, né, tem autoridade também, que também, tipo assim [...] resolve as coisas, é bom por isso" (Sempre-Viva, 31 anos, agricultora).

As falas dos homens expressam uma descontração apenas aparente para lidar com a nova situação que implica o questionamento de hierarquias relacionadas às relações entre produção e consumo. A possibilidade de relegar a um segundo plano a esfera da reprodução põe em questão certos princípios da tradição.

O fato de não participarem da gestão, no entanto, não exime as demais de um certo reposicionamento, mesmo que elas continuem "só fazendo a roça". Problemas relativos ao dendê com a vizinhança (por exemplo, incêndio em decorrência da queima por vizinhos para fazer a roça) são reportados a elas com tensões. O fato de terem a titularidade do contrato é reconhecido localmente como um distintivo e um sinal de uma nova posição. Esse entendimento nem sempre foi explícito nas suas falas.

Independentemente do tipo de explicação para a assinatura do contrato, duas situações são comuns para todas as mulheres: a relação com o banco e a participação em eventos promovidos pelas empresas agroindustriais. Pela formalidade, elas necessitam assinar para fechar contratos e retirar o dinheiro do financiamento e, com isso, relacionam-se com funcionários e, às vezes, com os gerentes, motivo de orgulho para elas. Assim, as mulheres transitam em outros espaços não habitualmente frequentados.

Se, por um lado, assinar contratos complexos, ir ao banco para resolver pendências e participar de reuniões com técnicos causa insegurança, por outro agrada pela importância atribuída aos contatos com atores de diferentes mundos sociais e com mulheres e homens que residem em outros lugares. Como explica Amaranto (agricultora, 40 anos): "Porque 0 projeto está em meu nome e sou sempre convocada, acho bom saber as coisas que estão acontecendo sobre o dendê, como o manejo, adubação e segurança do trabalho".

Mais do que aprendizados técnicos, as mulheres têm destacado a questão da autoestima, cujo símbolo é o acesso ao banco e a uma conta corrente após a obtenção do crédito para o cultivo do dendê. Assim, como apontado por Zanini \& Santos (2013), a ida ao banco e a participação de reuniões em sindicatos representam um novo panorama para as mulheres, embora ainda causem vergonha e constrangimento por causa do contato reduzido das mulheres com a esfera pública. À semelhança das autoras, analisaram-se essas participações como positivas.

Para Osorio Hernández (2009), a circulação das mulheres por espaços socialmente destinados aos homens insere-as em outras esferas da vida, externas ao ambiente familiar, o que demonstra reconhecimento social e contato com agentes de mediação e instituições.

\section{Conclusões}

Analisaram-se as razões pelas quais as mulheres assinaram contratos de integração para a produção de dendê e se essa condição influi em seu reposicionamento nas esferas doméstica e pública em São Domingos do Capim no contexto de incentivos públicos para a produção de agrocombustíveis no NEP. Nesse município, 198 agricultores (89\%) e 30 agricultoras (11\%) têm contrato de integração em seus nomes para a produção de dendê com duas agroindústrias desde 2012 (Banco da Amazônia, 2015).

O contrato em nome das mulheres ocorreu em decorrência: i) da iniciativa delas; ii) do atendimento à solicitação de um dos membros da família; e iii) de acordos familiares. Apesar da diferença dos motivos das mulheres, conclui-se que ter uma atividade remunerativa (crédito e mercado garantidos), garantir o bem-estar da família e ter a perspectiva de um futuro diferente para os filhos influenciou em todas as decisões. Ademais, elas e suas famílias vivenciam os limites do sistema de "corte e queima", a falta de assistência técnica e as vulnerabilidades do mercado. 
Mesmo assim, as vantagens atribuídas aos contratos, a complexidade e as diferentes visões quanto ao desenvolvimento rural dificultam consenso em torno das consequências da integração para as famílias dos agricultores entre os estudiosos do tema. Para uns, oportunidade de produção e mercado; para outros, subordinação e perda de autonomia sobre o trabalho e os meios de produção. Não obstante a divergência, conclui-se que, em geral, a autonomia sobre o processo produtivo sofre redução nos casos estudados. Entretanto, essa condição (a integração por contrato com a agroindústria) tem sido considerada como uma das raras possibilidades de obtenção de apoio econômico e técnico. Assim, não somente os aspectos econômicos e produtivos compõem a avaliação das agricultoras entrevistadas, porque: "Mais modestamente, o desejo de autonomia se manifesta na construção de uma zona de liberdade, que os sociólogos das organizações chamam de zona de incerteza" (Dubet, 2014, p. 124), no âmbito da qual novas relações podem potencializar a autonomia.

Constatou-se que a titularidade do contrato em nome de mulheres para a produção de dendê em estabelecimentos familiares influiu significativamente no reposicionamento de apenas três mulheres (10\%), o que permite a confirmação parcial da hipótese. Todas as três fazem parte do grupo que assinou o contrato por decisão própria e que se destaca pelo envolvimento nas atividades (operações agrícolas) diretamente na dendeicultura. Além de corresponderem aos critérios estipulados na hipótese, também acumulam experiências com a titularidade de outros projetos, têm vivência associativa (movimento social, associações, clube de mães e grupo de mulheres) e têm experiências de gestão de cultivos.

Mesmo com tal constatação, conclui-se que, de forma geral, a titularidade do contrato é determinante para que todas as mulheres envolvidas na pesquisa sejam reconhecidas nas localidades em que vivem como responsáveis pelo cultivo e transitem em outros espaços, nos quais entram em contato com atores de mundos sociais diferentes (agentes de capacitação, técnicos das empresas dendeicultoras e funcionários de bancos). Tais processos levam a aprendizados sociais importantes, com o reposicionamento delas em suas próprias famílias, pelo domínio e pela socialização de informações, condição anteriormente exclusiva dos homens.

Por fim, duas conclusões mais gerais. A titularidade do contrato é condição importante para a mudança nas relações de gênero por possibilitar às mulheres a defesa e a busca de seus interesses (Barbosa \& Lerrer, 2016), mas não é condição suficiente. Não obstante o reposicionamento das mulheres nas esferas privada e pública, persistem nos discursos, mas com menor intensidade nas práticas, os princípios da divisão sexual do trabalho quanto a trabalhos de homens e de mulheres e suas hierarquias (Hirata \& Kergoat, 2008).

\section{Referências}

Alves, S. A. O. (2011). Sustentabilidade da agroindústria da palma no Pará (Tese de doutorado). Universidade de São Paulo, Piracicaba.

Anjos, F. S. (1995). A agricultura familiar em transformação: o caso dos colonos-operários de Massaranduba (SC) (169 p.). Pelotas: UFPEL.

Aquino, S. L. (2013). Sobre agricultores, cultivo de eucalipto e estratégias agroindustriais: resistir e adaptarse ao sistema de produção integrada (Tese de doutorado). Universidade Federal Rural do Rio de Janeiro, Rio de Janeiro.

Arndt, C., Benfica, R., \& Thurlow, J. (2011). Gender implications of biofuels expansion in Africa: The case of Mozambique. World Development, 39(9), 1649-1662.

Backhouse, M. (2015). Grüne Landnahme: Palmölexpansion und Landkonflikte in Amazonien (264 p.). Münster: Verlag Westfälisches Dampfboot.

Barbosa, M. L. D. A., \& Lerrer, D. F. (2016). O gênero da posse da terra: um estudo sobre o poder de negociação de mulheres titulares de lotes via reforma agrária. Revista Brasileira de Sociologia, 4(8), 243-274.

Banco da Amazônia. Diretoria Comercial e de Distribuição. Gerência de Microfinanças e Agricultura Familiar. Coordenadoria de Agricultura Familiar. (2015). Sistema de relatórios. Belém: BASA. 
Becker, B. K. (2010). Recuperação de áreas desflorestadas da Amazônia: será pertinente o cultivo da palma de óleo (Dendê)? Confins, (10). Recuperado em 5 de julho de 2013, de http://confins.revues.org/6609

Brandão, F., \& Schoneveld, G. (2015). The state of oil palm development in the Brazilian Amazon: trends, value chain dynamics, and business models (Working Paper, No. 198). Bogor, Indonesia: CIFOR.

Brandão, F., Schoneveld, G., \& Pacheco, P. (2018). Integração da agricultura familiar à cadeia da palma de óleo na Amazônia brasileira: análises e recomendações (Infobrief, No. 207). CIFOR.

Brasil. Instituto Nacional de Colonização e Reforma Agrária - INCRA. (2020). Instrução normativa $n^{\circ} 38$, de 13 de março de 2007. Diário Oficial [da] Republica Federativa do Brasil, Brasília. Seção I, pág 57 e BS n ${ }^{\circ} 12$ de 19 de março de 2007. Recuperado em 27 de maio de 2020, de http://www.incra.gov.br/sites/default/files/uploads/institucionall/legislacao--/atosinternos/instrucoes/in38_130307.pdf

Caseiro, C. (2011). A produção e o consumo de biocombustíveis no mundo atual: questões-chave para analisar a sua sustentabilidade. Campo-Território, 6(12), 6-31.

Castro, E. (2012). Expansão da fronteira, megaprojetos de infraestrutura e integração sul-americana. Caderno $C R H, 25(64), 45-61$.

Costa, A. J. D. (1993). O grupo Sadia e a produção integrada: o lugar do agricultor no complexo agroindustrial (Dissertação de mestrado). Universidade Federal do Paraná, Curitiba.

Costa, S. S. S. (2016). Sindicato é pra quem entende: (des)igualdades de gênero no sindicalismo dos empregados rurais de Moju-PA (Dissertação de mestrado). Universidade Federal do Pará, Belém.

Dubet, F. (2014). Injustiças: a experiência das desigualdades no trabalho (403 p.). Florianópolis: Editora UFSC.

Garcia Júnior, A. R. (1983). Terra de trabalho, trabalho familiar e pequenos produtores (236 p.). Rio de Janeiro: Paz e Terra.

Gaspari, L. C., \& Khatounian, C. A. (2016). Características das famílias, estruturação da produção e estratégias de comercialização em um assentamento de reforma agrária. Revista de Economia e Sociologia Rural, 54(2), 243-260.

Gomes, L. S., \& Magalhães, S. B. (2016). Agricultores integrados do dendê e questões relativas ao sistema de produção no PA, Terra Nova. EcoDebate. Recuperado em 31 de janeiro de 2017, de https://www.ecodebate.com.br/2016/05/30/agricultores-integrados-do-dende-e-questoes-relativasao-sistema-de-producao-no-pa-terra-nova-por-lucinaldo-soares-gomes-e-sonia-barbosamagalhaes/

Hirata, H., \& Kergoat, D. (2007). Novas configurações da divisão sexual do trabalho. Cadernos de Pesquisa, 37(132), 595-609.

Hirata, H., \& Kergoat, D. (2008). Divisão sexual do trabalho profissional e doméstico: Brasil, França, Japão. In A. Costa, B. Sorj, C. Bruschini \& H. Hirata (Eds.), Mercado de trabalho e gênero: comparações internacionais (pp. 263-278). Rio de Janeiro: FGV.

Homma, A. O. K., \& Vieira, I. C. G. (2012). Colóquio sobre dendezeiro: prioridades de pesquisas econômicas, sociais e ambientais na Amazônia. Amazônia. Ciência \& Desenvolvimento, 8(15), 79-90.

Instituto Brasileiro de Geografia e Estatística - IBGE. (2015). Cidades. Rio de Janeiro: IBGE. Recuperado em 10 de dezembro de 2017, de https://cidades.ibge.gov.br/brasil/pa/sao-domingos-docapim/panorama

Instituto Brasileiro de Geografia e Estatística - IBGE. (2017). Produção agrícola municipal: lavoura permanente e produção agrícola municipal: lavoura temporária. Rio de Janeiro: IBGE. Recuperado em 20 de outubro de 2017, de https://cidades.ibge.gov.br/xtras/perfil.php?codmun=150720

Instituto Nacional de Colonização e Reforma Agrária - INCRA. Diretoria de Obtenção de Terras e Implantação de Projetos de Assentamento. Coordenação-Geral de Implantação. (2015). Projetos criados (329 p.). Brasília: INCRA. Recuperado em 10 de agosto de 2017, de http://www.incra.gov.br/sites/default/files/uploads/reforma-agraria/questao-graria/reformaagraria/projetos_criados-geral.pdf

Instituto Nacional de Colonização e Reforma Agrária - INCRA. (2020). Portaria INCRA n 981 de 02 de outubro de 2003. Altera a Norma de Execução SDA n 29 de 2002. Brasil, 2003. Recuperado em 28 de maio de 2020, de https://i3gov.planejamento.gov.br/dadosgov/textos/livro2/2.3_Reforma_Agraria.pdf

Julia, \& White, B. (2012). Gendered experiences of dispossession: oil palm expansion in a Dayak Hibun community in West Kalimantan. Peasant Studies, 39(3-4), 995-1016. 
Laschefski, K. (2010). Agrocombustíveis: a caminho de um novo imperialismo ecológico? In A. Zhouri \& K. Laschefski (Eds.), Desenvolvimento e conflitos ambientais (pp. 63-91.). Belo Horizonte: Editora UFMG.

Li, T. M. (2014). The gendered dynamics of Indonesia's oil palm labour regime (Working Paper Series, No. 225). Singapore: Asia Research Institute.

Lima, B. F., \& Mota, D. M. (2016). Percepção de mulheres extrativistas sobre o trabalho na ilha de Marajó-Pará. Ideias, 7, 89-110.

Magalhães, S. B. (2003). Direitos e projetos: uma leitura sobre a implantação dos assentamentos no Sudeste do Pará. In J. S. Martins (Ed.), Travessias: a vivência da reforma agrária nos assentamentos (pp. 202-294). Porto Alegre: UFRGS.

Monteiro, K. F. G. (2013). Análise de indicadores de sustentabilidade socioambiental em diferentes sistemas produtivos com palma de óleo no Estado do Pará (Tese de doutorado). Universidade Federal Rural da Amazônia, Embrapa Amazônia Oriental, Belém.

Mota, M. D., Silva, E. M., Schmitz, H., Navegantes-Alves, L., \& Ferreira, M. S. G. (2015). Produção de culturas alimentares e dendê nos estabelecimentos familiares no Nordeste Paraense. In Anais do Seminário Internacional América Latina: Política e Conflitos Contemporâneos. Belém.

Motta-Maués, M. A. (1993). "Trabalhadeiras" e "camarados": relações de gênero, simbolismo e ritualização numa comunidade amazônica (228p.). Belém: CFCH, UFPA.

Nahum, J. S., \& Murray, J. D. (2014). Impactos socioespacais da dendeicultura no Brasil e na Colômbia. In Anais do $7^{\circ}$ Congresso Brasileiro de Geógrafos (pp. 1-11). Vitória, ES.

Nahum, J. S., \& Santos, C. B. (2014). Impactos socioambientais da dendeicultura em comunidades tradicionais na Amazônia paraense. In J. S. Nahum (Ed.), Dendeicultura e dinâmicas territoriais do espaço agrário na Amazônia paraense (pp. 55-72). Belém: GAPTA/UFPA.

Neves, D. P. (2014). Mulheres e mercado de trabalho: afiliações e conquistas. Niterói: Alternativa.

Nogueira, C. M., \& Jesus, E. (2013). A pequena produção avícola familiar e o sistema de integração no Oeste catarinense: uma prisão de portas abertas. Caderno CRH, 26(67), 123-138.

Norwana, A. W. A. B. D., Kunjappan, R., Chin, M., Schoneveld, G., Potter, L., \& Andriani, R. (2011). The local impacts of oil palm expansion in Malaysia: an assessment based on a case study in Sabah State (26 p.). Bogor, Indonesia: CIFOR.

Osorio Hernández, C. (2009). Política de crédito rural com perspectiva de gênero: um meio de "empoderamento" para as mulheres rurais? (Tese de doutorado). Universidade Federal do Rio Grande do Sul, Porto Alegre.

Paulilo, M. I. S. (1990). Produtor e agroindústria: consensos e dissensos: o caso de Santa Catarina. Florianópolis: UFSC.

Paulilo, M. I. S. (1987). O peso do trabalho leve. Revista Ciência Hoje, 5(28), 64-70.

Picanço Filho, A. F., \& Marin, J. O. B. (2012). Contratos de fornecimento de cana-de-açúcar: as assimetrias de poder entre os agentes. Interações, 13(2), 191-202.

Raynolds, L. T. (2002). Wages for wives: renegotiating gender and production relations in contract farming in the Dominican Republic. World Development, 30(5), 783-798.

Reigada, A. (2014). Um olhar feminista sobre o trabalho nas cadeias agrícolas globais. Contemporanea, 4(1), 19-41.

Repórter Brasil. (2013). Expansão do dendê na Amazônia brasileira: elementos para uma análise dos impactos sobre a agricultura familiar no nordeste do Pará. São Paulo. Recuperado em 20 de outubro de 2013, de http://reporterbrasil.org.br/documentos/Dende2013.pdf

Ribeiro, L. B. (2016). O trabalho sob influência da dendeicultura em vilas rurais paraenses (Dissertação de mestrado). Universidade Federal do Pará, Belém.

Sampaio, I. C. (2014). A agricultura familiar e a agroindústria do dendê no município de Tomé Açu (PA): efeitos da agricultura por contrato na produção e no trabalho familiar (Dissertação de mestrado). Universidade Federal do Pará, Belém.

Santos, C. B. D. (2015). Dendeicultura e comunidades na Amazônia paraense: uma análise do município de Moju. Belém: Itacaiúnas.

Schmitz, H. (2013). Desenvolvimento sustentável da Amazônia, camponeses e uso da terra: a produção científica de Thomas Hurtienne desde 1994. Novos Cadernos Naea, 16(2), 341-357.

Silva, E. M. (2016). Expansão da dendeicultura e transformações nos sistemas de produção familiares na Amazônia Oriental (Dissertação de mestrado). Universidade Federal do Pará, Belém. 
Sorj, B. (1986). Estado e classes sociais na agricultura brasileira (2. ed.). Rio de Janeiro: Zahar.

Vieira, A. C. (2015). "Integração" camponesa ao monocultivo de dendê: subordinação e transformação do campesinato amazônico (Dissertação de mestrado). Universidade Federal do Pará, Belém.

Vieira, A. C., \& Magalhães, S. B. (2013). Transformações no espaço rural amazônico: o plantio de dendê em comunidades camponesas do Baixo Tocantins, município de Moju/PA. In Anais do $2^{\circ}$ Seminário Internacional Ruralidades, Trabalho e Meio Ambiente. São Carlos: UFSCar.

Vieira, N., Siqueira, D., \& Di Paolo, D. (2014). “O que é de mulher e o que é de homem”: relações de gênero na pesca artesanal, comunidade de Bonifácio, Amazônia Oriental, Brasil. Raízes, 34(1), 8-23.

Watanabe, K., \& Zylbersztajn, D. (2014). Contract farming in the Brazilian agri-business system: private institutions and State intervention. Uniform Law Review, 19, 459-478.

Wedig, J. C., \& Menasche, R. (2013). Práticas alimentares entre camponeses: expressão de relações familiares e de gênero. In D. P. Neves \& L. S. Medeiros (Eds.), Mulheres camponesas: trabalho produtivo e engajamentos políticos (pp. 147-162). Niterói: Alternativa.

Woortmann, K., \& Woortmann, E. F. (2002). Monoparentalidade e chefia feminina: conceitos, contextos e circunstâncias. In Pré-evento Mulheres Chefes de Família: Crescimento, Diversidade e Políticas (99 p.). Ouro Preto: CNPD, FNUAP, ABEP. Recuperado em 10 de dezembro de 2017, de https://parentescoeorg.files.wordpress.com/2010/08/artigo-woortmann-klaass-e-ellenmonoparentalidades-e-chefia-feminina-conceitos-contextos-e-circunstancias1.pdf

Zanini, M. C. C., \& Santos, M. O. (2013). Colônias italianas no Sul do Brasil: estigma e identidade. In D. P. Neves \& L. S. Medeiros (Eds.), Mulheres camponesas: trabalho produtivo e engajamentos políticos (pp. 89-106). Niterói: Alternativa.

Data de submissão: 12/Março/2018.

Data de aceite: $7 /$ Set./2019

Classificação JEL: Z1 